ber of years in building. It will be opened on Sept. 12,1892, and will close on Dec. 31 of the same year, thus preceding the Chicago exhibition, which it is designed, in a measure, to supplement. All objects, if securely and properly packed, will be forwarded gratis to Madrid, and returned to the exhibitor free of expense, the exhibition not only bearing the cust of transportion, but also, when desired, attending to the arrangement and display of the objects without any charge. Those who desire special cases of their own may provide them, and special buildings may also be erected in the park if the design is approved by the general committee. All objects for the exbibition will be admitted duty free into Spain if they are withdrawn at the close of the exhibition, but two months will be allowed after the end of the exhibition before articles need be returned.

An international jury, proportionate to the number of the exhibitors from different countries and the importance of their exhibits, will examine the articles displayed and award the prizes. These will consist of a first prize of honor, a gold medal, a silver medal, a bronze medal, and honorable mention, each medal being accompanied with a diploma.

The exhibition covers, of course, the entire American continent, but to insure its complete success the active co-operation and assistance of citizens of the United States is especially desired. There is every reason why Americans should both be interested in this exhibition and take part in it. The conditions are liberal, the prizes ample, and the time is especially convenient to intending exhibitors at the Chicago exhibition, as objects may be exhibited both at Madrid and at Chicago. Nor is the novelty of the exhibition its least merit. Early American history has always been a favorite topic of study among European scholars, but it is safe to say that if this exhibition is carried out as it is planned, it will offer Europeans the first opportunity they have had to study primitive American life in its completeness. American collections are very rich in the materials most desired at Madrid, and it is most sincerely to be hoped that the gracious invitation of the Spanish people to participate in their Columbian celebration will meet with a generous and hearty support from American scholars and collectors.

Barr Ferree.

$$
\text { New York. }
$$

\section{At What Time were the Galapagos Islands Discovered?}

I SHOULD be greatly obliged to anyone who could give me some information in regard to the discovery of the Galapagos Islands. The first notice I have been able to find is in the Atlas of Abraham Ortelius, published in 1.570, where the Islands are spelled "Galopegos" and "Galepegos" (Ortelius, Abraham, "Typus Orbis Terrarum," 1570; second edition, 1580; "Theatrum oder Schaubuch des Erdkreys, Autdorff, Americae sive novi orbis novae descriptio;" 1570). On the splendid map of Diego Ribero, prepared between 1527 and 1529, the Galapayos Islands are not represented (Ribero, Diego, J. G. Kohl, " Die beiden aeltesten General Karten von America ausgeführt in den Jahren, $152 \tau$ and 1529, auf Befehl Kaiser Carl's, v.," Weimar, 1860). It seems therefore probable that these islands were discovered in the beginning of the sixteenth century, before 15\%0. The word galapago itself seems to be of South American origin; it means land-tortoise G. BAUR.

Clark Untversity, Worcester, Mass., Jan. 10.

\section{BOOK-REVIEWS.}

School and College; devoted to secondary and higher education. Edited by Ray Greene Huling. Vol. I., No. 1, January, 1892. Boston, Ginn \& Co.

MAGAZINES and newspapers devoted to educational subjects multiply apace, so that if our teachers are not properly informed on matters relating to their work, it will not be for want of the means of intercommunication. This latest comer in the field is a magazine of sixty-four pages, to be issued every month except July and August, at twenty cents a number, or $\$ 1.50$ a year. The articles in this opening number show very plainly the influence of the educational ideas just now prevalent; indeed, they may be said to show little else. The writers appear to agree that the study of Greek is destined to be abandoned; though the editor speaks of this as an event that is inevitable rather than as one to be desired. The most interesting paper in the magazine is that by President Andrews of Brown Unirersity on "Some of the Next Steps Forward in Education," its most important point being the suggestion that teachers ought to enter into closer moral and social relations with their pupils. Mr. B. C. Burt has an article advocating the beginning of philosophical study at an earlier age than is now customary ; but unless the subject can be made more easily intelligible than it is in his article, we fear that his wishes will not be realized. Mr. John Tetlow gives an account of " The Greek Method of Performing Arithmetical Operations," which will be of interest to mathematical students; and Mr. James H. Blodgett has a brief paper on "Secondary Education in Census Years." The rest of the magazine is occupied with educational news, both domestic and foreign, a few book reviews of no great value, and several brief "Letters to the Editor." The new magazine has some good points, and its field, though narrow, may be made interesting by proper cultivation; but it seems to us that an improvement in the quality of our educational literature is more important than an increase in its quantity.

Geological Survey of Alabama. EuGEne Allen Smith, Ph.D., State Geologist. Report on the Coal Measures of the Plateau Region of Alabama, by Henry McCalley, Assistant State Geologist, including a report on the Coal Measures of Blount County, by A. M. Gibson, with a Map of the Coal-Fields and two Colored Geological Sections across the Plateau Region and Intermediate Valleys. Montgomery, Ala., 1891.

IN the Report of Progress of the Alabama Geological Survey, for the years 1877-8, the division of the Warrior Coal-Field into "Plateau Region" and "Warrior Basin" was first made by Dr. Smith, the State geologist. Characteristic of the Plateau Region is the circumstance that the limestone beds which underlie the capping of Coal Measures are above the general drainage level of the country. This arrangement of the two classes of strata determines in great measure the character of the scenery, for the removal by erosion of the more perishable limestone causes the undermining of the harder strata above, which from time to time break off with nearly vertical faces, forming cliffs which overlook all the valleys. The three principal valleys that traverse this region, in a north-east and south-west direction, are anticlinal valleys, more or less complicated by faulting and overlapping; they are Wills's, Murphree's, and Brown's Valleys, the latter being an extension into this State of the great Sequatchee Valley of Tennessee. Between these anticlinals the Coal Measures occupy shallow synclinal troughs, which also show secondary undulations, with axes nearly at a right angle to the axes of the synclinals and anticlinals, i.e., approximately north-west and south-east. In the anticlinal valleys strata down to the Cambrian are exposed, but in the smaller valleys, cut by streams in the synclinal troughs, oniy the subcarboniferous measures are reached by the erosion.

Towards the south-west the Coal Measures and their underlying strata slope gradually and more rapidly than the topography, and the Plateau Region thus grades insensibly into the Basin, where none of the beds underlying the coal are above drainage. In the Plateau Region, and particularly in its north-eastern portion, only the lowest of the rocks of the Coal Measures are left capping the mountains, viz., the two conglomerates with their intervening and underlying beds; but further towards the south-west, other higher members of the Coal Measures come in and the plateau like character is in equal measure lost.

The Report for $1877-8$, above referred to, and a subsequent Report for 1879-80, contained notes chiefly on the Coal Measures of the Warrior Basin. In 1886 a large volume from the pen of $\mathrm{Mr}$. McCalley, "On the Warrior Field," was published by the survey. This report also was concerned chiefly with the Measures of the Warrior Basin, though containing some notes on part of the Plateau Region. The present volume deals with the Measures of the Plateau Region alone, and presents about all the information at this time available. The two colored sections exhibit well the geological and topograhic features of this region, and show the gradual sinking of the strata towards the south-west and the passage into the Basin proper. 